\title{
ВЛИЯНИЕ УГЛЕВОДОВ НА БИОСИНТЕЗ НУКЛЕИНОВЫХ КИСЛОТ И БЕЛКОВ В ПРОРАСТАЮЩИХ СЕМЕНАХ ПШЕНИЦЫ СОРТА БУРЯТСКАЯ ОСТИСТАЯ
}

\section{A.K. Podshivalova, E.S. Gogol \\ THE INFLUENCE OF CARBOHYDRATES ON THE BIOSYNTHESIS OF NUCLEIC ACIDS AND PROTEINS IN GERMINATING WHEAT GRAINS OF THE VARIETY 'BURYATSKAYA OSTISTAYA'}

Подшивалова Анна Кирилловна - канд. хим. наук, доц., зав. каф. неорганической, органической и биологической химии Иркутского государственного аграрного университета им. А.А. Ежевского, Иркутская обл., Иркутский р-н, пос. Молодежный. E-mail: chem.acad.38@yandex.ru

Гоголь Елена Сергеевна - ст. преп. каф. неорганической, органической и биологической химии Иркутского государственного аграрного университета им. А.А. Ежевского, Иркутская обл., Иркутский р-н, пос. Молодежный.

E-mail: chem.acad.38@yandex.ru

Исследовали влияние углеводов на общее содержание нуклеиновых кислот и содержание суммарного белка в проросших семенах пшениuы сорта Бурятская остистая. Семена проращивали в растворах углеводов: простых (әлюкоза, сахароза) и сложных (арабиногалактан). Температура проращивания составляла 24$26^{\circ} \mathrm{C}$. Продолжительность проращивания - 3 суток. Концентрация сахаров в растворах для проращивания - 0,1% (масс). Суммарное содержание нуклеиновых кислот в проросших зернах пшеницы и общее содержание белков определяли спектрофоотометрическим методом. Выявлено, что среда для прорастания существенно влияет на показатели прорастания семян пшеницы сорта Бурятская остистая. Биосинтез нуклеиновых кислот усиливается при прорастании семян в растворах всех углеводов по сравнению с контролем (вода). При прорастании семян в растворах простых углеводов (глюкоза, сахароза) содержание нуклеиновых кислот почти одинаковое, а растворы сложного углевода (арабиногалактан) обеспечивают резкое увеличение содержания нуклеиновых кислот в проростках. В целом для проросших зерен пшенищы благоприятное влияние среды для про-
Podshivalova Anna Kirillovna - Cand. Chem. Sci., Assoc. Prof., Head, Chair of Inorganic, Organic and Biological Chemistry, Irkutsk State Agrarian University named after A.A. Ezhevsky, Irkutsk Region, Irkutsk District, S. Molodezhny.

E-mail: chem.acad.38@yandex.ru

Gogol Elena Sergeevna - Senior Lecturer, Chair of Inorganic, Organic and Biological Chemistry, Irkutsk State Agrarian University named after A.A. Ezhevsky, Irkutsk Region, Irkutsk District, S. Molodezhny. E-mail: chem.acad.38@yandex.ru

растания на суммарное содержание нуклеиновых кислот усиливается в ряду: вода - глюкоза - сахароза - арабиногалактан. Наибольшее содержание белка в проростках выявлено для растворов сахарозы, минимальное из исследуемых сахаров - для растворов арабиногалактана. Последовательность увеличения содержания белка в проросших зернах пшеницы в зависимости от среды для прорастания имеет вид: вода - арабиногалактан - глюкоза - сахароза. По сравнению с сухими зернами в проростках для растворов әлюкозы и сахарозы показатели увеличения содержания нуклеиновых кислот и белков практически совпадают. Наибольшая разница этих процессов наблюдается для растворов арабиногалактана: содержание нуклеиновых кислот резко возрастает по сравнению с другими растворами, а содержание белка, напротив, снижается по сравнению с растворами простых углеводов. В зерновках при проращивании зерен в растворах сахаров содержание нуклеиновых кислот увеличивается по сравнению с сухими зернами, а белка - снижается.

Ключевые слова: нуклеиновые кислоты, белки, злаковые культуры. 
The germination medium influences on germination rates of wheat grains of Buryatskaya ostistaya" variety was studied. The seeds were germinating in solutions of carbohydrates: simple (glucose, sucrose) and comlex (arabinogalactan). The temperature of germinating made $24-26{ }^{\circ} \mathrm{C}$. The duration of germination was 3 days. The concentration of sugars in the solutions for germination was $0.1 \%$ (masses). The total content of nucleinic acids in sprouted grains of wheat and the general content of proteins were determined by spectrofotometric method. It was revealed that the environment for germination significantly influenced the indicators of germination of seeds of wheat of the variety Buryatskaya ostistaya. Biosynthesis of nucleinic acids amplified at germination of seeds in solutions of all carbohydrates in comparison with control (water). When the grains germinated in the solutions of simple carbohydrates (glucose, sucrose), nucleic acid content was almost the same, and the complex carbohydrate solutions (arabinogalactan) provided sharp increase in the content of nucleic acids in the acrospires. In general for the sprouted wheat grains beneficial effect of the environment for germination on the total content of nucleic acids enhanced in the series: water - glucose - sucrose arabinogalactan. The highest protein content in the acrospires was found for the sucrose solutions of the studied sugars, and the lowest was for the arabinogalactan solutions. The sequence of increase in protein content in germinated wheat grains depending on the medium for germination was: water - arabinogalactan - glucose - sucrose. Compared to dry grains, in the acrospires germinated in the glucose and sucrose solutions the rates of increase in the content of nucleic acids and proteins almost coincided. The greatest difference between these processes was observed for the solutions of arabinogalactan: the content of nucleic acids increasedsharply in comparison to the other solutions, and the protein content, in contrast, decreased in comparison to the solutions of simple carbohydrates. During the germination of grains in sugar solutions, the content of nucleic acids increases compared to dry grains, and protein decreased.

Keywords: nucleic acids, proteins, cereals.
Введение. Значительное количество научных исследований связано с поиском возможностей стимулирования роста и развития растений, стабилизации урожая, повышения неспецифической устойчивости к различного рода абиотическим и биотическим стрессам. Развитие и продвижение этих технологий невозможно без глубокого понимания механизмов процессов прорастания семян, сопровождающихся активацией генома и различных фризиолого-биохимических процессов.

Известно, что нуклеиновые кислоты выполняют важнейшую роль в метаболических процессах, протекающих в растениях. Суммарное количество ДНК и РНК, их соотношение, форма нахождения (лабильная и стабильная фрракции), способность образования ассоциатов с другими макромолекулами и иные факторы оказывают значительное влияние на характеристики развития растений, их урожайность и адаптивные свойства.

По литературным данным, количественный и фрракционный состав нуклеиновых кислот можно изменять под действием регуляторов роста и развития растений [1-2], особенностей произрастания [3], регуляции температурного режима с использованием, в частности, специфических белков [4-5]. Содержание нуклеиновых кислот, а также соотношение ДНК и РНК существенным образом зависят от сроков хранения семян [6] и региона выращивания [7].

Нуклеиновые кислоты, содержащиеся в растениях как продуктах питания, оказывают большое влияние на метаболические процессы в животных организмах, в частности в организме человека. Они способны активировать рецепторы, запускающие транскрипцию генов, встраиваться в физиологические процессы, влияющие на активность генома человека [8].

Биосинтез и фризиологическая деятельность нуклеиновых кислот неотъемлемо связаны с биосинтезом белка, биологическая роль которого во множественных аспектах также бесспорна.

Процессы биосинтеза нуклеиновых кислот, белков, ферментов и иных участников обменных процессов в растениях активизируются при прорастании семян. Именно поэтому в настоящее время широко используются продукты переработки проросших семян, в частности пшеничных зародышей [9]. 
Таким образом, наиболее значительные изменения количественного и фрракционного содержания нуклеиновых кислот происходят в процессе прорастания семян с последующей экстраполяцией этих изменений на особенности белкового, фрерментативного, углеводного, липидного обменов в растениях и, как следствие, показателей развития, урожайности и питательной ценности растений.

Углеводы играют значительную роль в энергетическом жизнеобеспечении клеток зародыша, выходящего из покоя, путем поддержания достаточно сложного комплекса окислительновосстановительных реакций. Промежуточные продукты метаболизма углеводов являются связующим звеном между обменом аминокислот и нуклеотидов.

Цель исследования. Изучение влияния простых и сложных углеводов на общее содержание нуклеиновых кислот и содержание суммарного белка в проросших семенах пшеницы сорта Бурятская остистая.

Объекты и методы исследования. Семена пшеницы сорта Бурятская остистая урожая 2018 года проращивали в растворах углеводов: простых (глюкоза, сахароза) и сложных (арабиногалактан). Температура проращивания составляла
24-26 ${ }^{\circ} \mathrm{C}$. Продолжительность проращивания 3 суток. Концентрация сахаров в растворах для проращивания - 0,1 \% (масс). Повторность опытов - трехкратная.

Суммарное содержание нуклеиновых кислот в проросших зернах пшеницы определяли спектрофотометрическим методом по методике, изложенной в работе [10]. Общее содержание белков определяли также спектрофотометрически по методике [11].

Результаты и их обсуждение. По результатам исследования, среда для прорастания значительно влияет на показатели прорастания семян пшеницы сорта Бурятская остистая.

Как следует из данных, представленных на рисунке 1, биосинтез нуклеиновых кислот усиливается при прорастании семян в растворах всех углеводов по сравнению с контролем (вода). При этом, как и следовало ожидать, наибольшей эфффективностью биосинтеза нуклеиновых кислот характеризуются проростки. При прорастании семян в растворах простых углеводов (глюкоза, сахароза) содержание нуклеиновых кислот почти одинаковое, а растворы сложного углевода (арабиногалактан) обеспечивают резкое увеличение содержания нуклеиновых кислот в проростках.

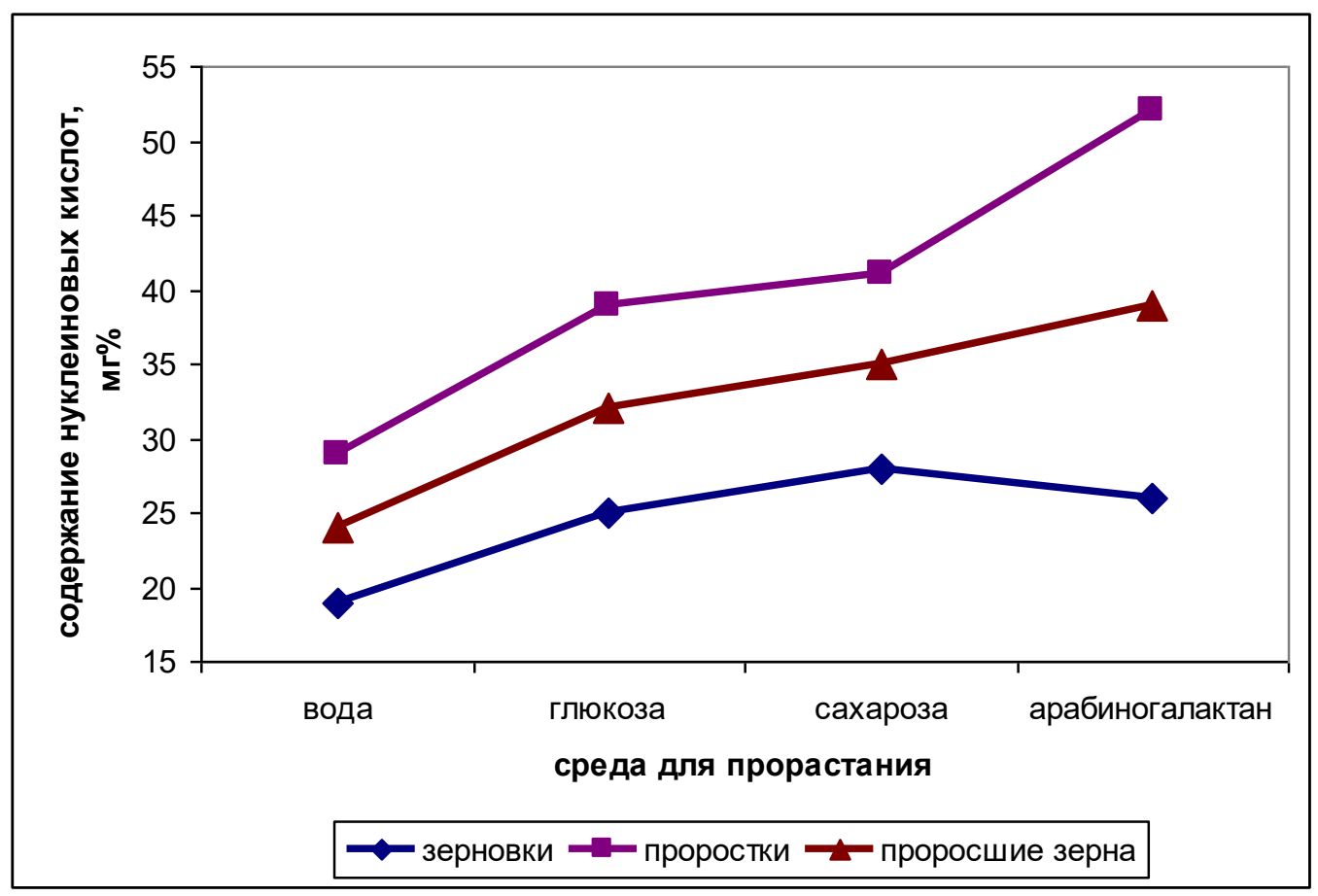

Puc. 1. Зависимость суммарного содержания нуклеиновых кислот в семенах пшеницы от среды для прорастания 
В зерновках биосинтезу нуклеиновых кислот (в значительно меньшей степени, чем для проростков) способствуют растворы сахарозы. В растворах арабиногалактана и глюкозы показатели примерно одинаковые.

В целом для проросших зерен пшеницы благоприятное влияние среды для прорастания на суммарное содержание нуклеиновых кислот усиливается в ряду

вода - глюкоза - сахароза - арабиногалактан.
Влияние среды для прорастания семян пшеницы на содержание общего белка (рис. 2) имеет несколько иной характер, чем для нуклеиновых кислот, хотя есть и общие закономерности. В частности, следует отметить, что наиболее активно биосинтез белков, как и биосинтез нуклеиновых кислот, протекает в проростках. При этом наибольшее содержание белка в проростках выявлено для растворов сахарозы, минимальное из исследуемых сахаров - для растворов арабиногалактана.

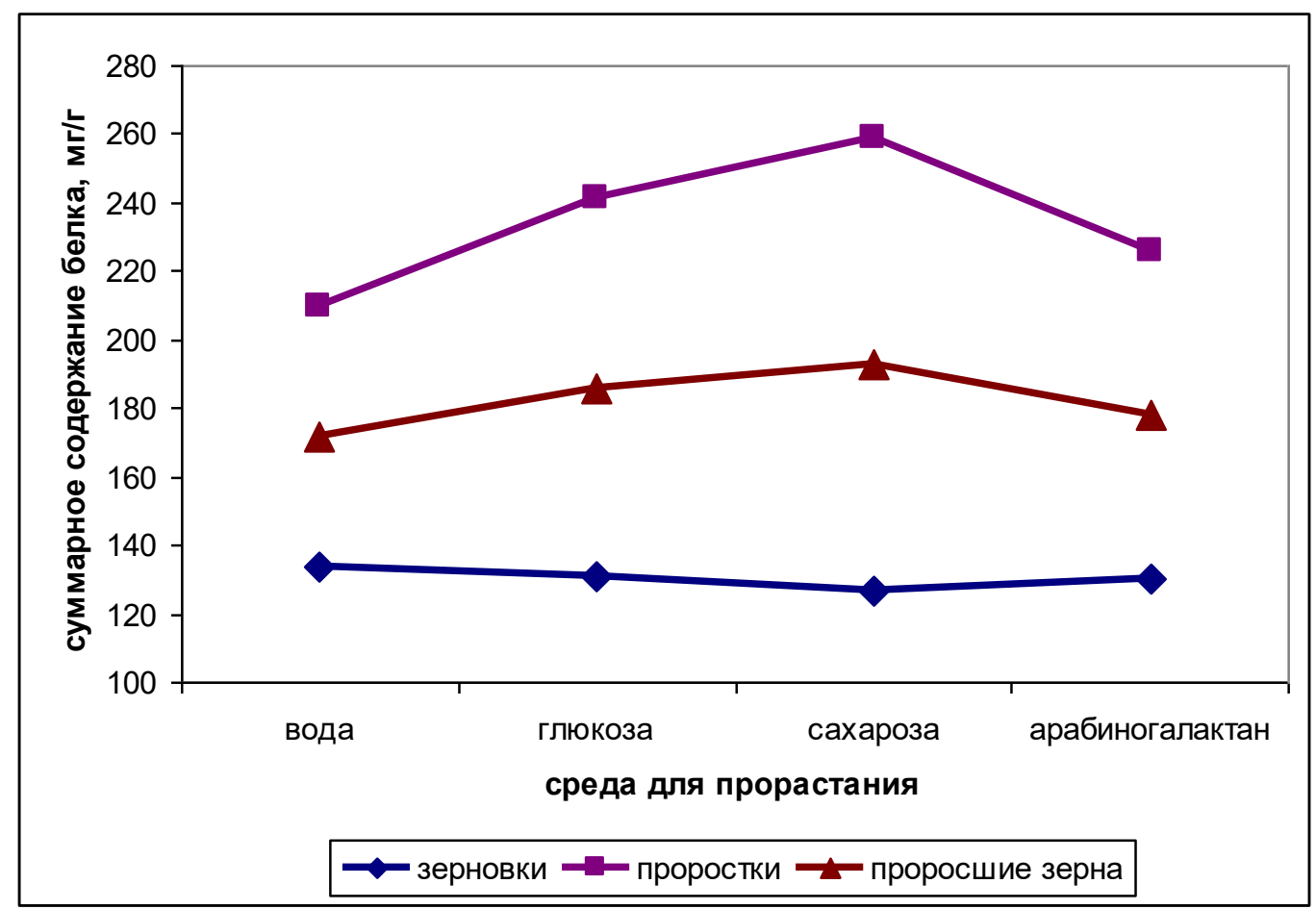

Puс. 2. Зависимость содержания суммарных белков в семенах пшеницы от среды для прорастания

Кривая для зерновок в определенном смысле симметрична кривой для проростков, а именно: чем больше содержание белков в проростках, тем меньше в зерновках.

Последовательность увеличения содержания белка в проросших зернах пшеницы в зависимости от среды для прорастания имеет вид вода - арабиногалактан - глюкоза - сахароза.

Представляет интерес взаимосвязь содержания нуклеиновых кислот и белков в проросших семенах пшеницы относительно исходного их содержания в сухих зернах. Соответствующие показатели для сухих зерен пшеницы: суммарное содержание нуклеиновых кислот 22 мг\%, общий белок - 141 мг/г.
По данным, представленным на рисунке 3, в проростках для растворов глюкозы и сахарозы показатели увеличения содержания нуклеиновых кислот и белков по сравнению с сухими зернами практически совпадают. В воде эффрективность биосинтеза белков несколько выше, чем нуклеиновых кислот. И наибольшая разница этих процессов наблюдается для растворов арабиногалактана: содержание нуклеиновых кислот резко возрастает по сравнению с другими растворами, а содержание белка, напротив, снижается по сравнению с растворами простых углеводов. 


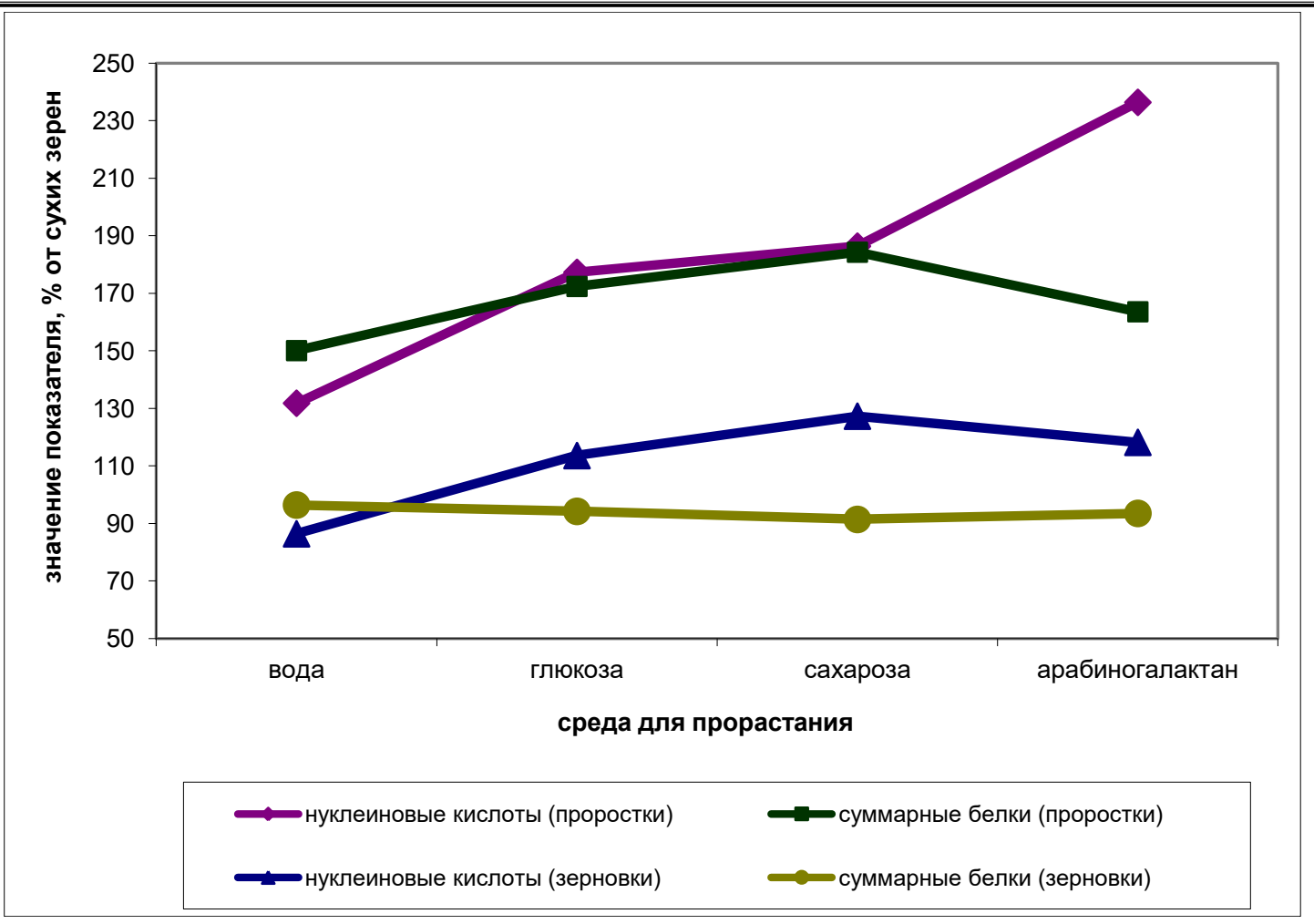

Puc. 3. Содержание нуклеиновых кислот и белков в проросших семенах пшеницы по отношению к сухим зернам

В научных публикациях обсуждаются результаты изучения взаимосвязи процессов биосинтеза белков и нуклеиновых кислот [12], влияния факторов на биосинтез белков в злаковых культурах [13-14], и конкретизация полученных данных требует более глубокого изучения этих процессов. Что касается арабиногалактана, то можно предположить, что одной из причин особенного его влияния на процессы биосинтеза белка в семенах пшеницы является то, что в состав макромолекулы природного полисахарида арабиногалактан входят остатки галактозы и арабинозы, и продукты гидролиза арабиногалактана могут особенным образом участвовать в метаболических процессах в растении.

В зерновках при проращивании зерен в растворах сахаров содержание нуклеиновых кислот увеличивается по сравнению с сухими зернами, а белка - снижается.

\section{Выводы}

1. Наличие углеводов в растворах для прорастания семян пшеницы сорта Бурятская остистая существенно влияет на эфффективность биосинтеза нуклеиновых кислот и белков в прорастающих зернах.

2. Биосинтез нуклеиновых кислот усиливается при прорастании семян в растворах всех углеводов по сравнению с контролем (вода). При прорастании семян в растворах простых углеводов (глюкоза, сахароза) содержание нуклеиновых кислот почти одинаковое, а растворы сложного углевода (арабиногалактан) обеспечивают резкое увеличение содержания нуклеиновых кислот в проростках. В целом для проросших зерен пшеницы благоприятное влияние среды для прорастания на суммарное содержание нуклеиновых кислот усиливается в ряду: вода - глюкоза - сахароза - арабиногалактан.

3. Наибольшее содержание белка в проростках выявлено для растворов сахарозы, минимальное из исследуемых сахаров - для растворов арабиногалактана. Последовательность увеличения содержания белка в проросших зернах пшеницы в зависимости от среды для прорастания имеет вид: вода - арабиногалактан - глюкоза - сахароза.

4. По сравнению с сухими зернами в проростках для растворов глюкозы и сахарозы показатели увеличения содержания нуклеиновых 
кислот и белков практически совпадают. Наибольшая разница этих процессов наблюдается для растворов арабиногалактана: содержание нуклеиновых кислот резко возрастает по сравнению с другими растворами, а содержание белка, напротив, снижается по сравнению с растворами простых углеводов.

В зерновках при проращивании зерен в растворах сахаров содержание нуклеиновых кислот увеличивается по сравнению с сухими зернами, а белка - снижается.

\section{Литература}

1. Мамедова А.Д., Алиев Р.Т. Изучение активности синтеза нуклеиновых кислот при гетерозисе и стимуляции ростовых процессов, вызываемых действием гидразида малеиновой кислоты // Известия вузов. Северо-Кавказский регион. Естественные науки. 2016. № 3. C. 36-40.

2. Барашкова Н.В., Неустроева Е.Р. Влияние стимулятора роста «Крезацин» на рост и развитие костреца безостого в условиях долины Средней Лены // Наука и образование. 2017. № 4. С. 99-103.

3. Влияние техногенного засоления на фракционный состав фосффорных соединений растений / М.Г. Кусакина, О.3. Еремченко, Н.В. Орлова [и др.] // Вестник Пермского университета. Сер. Биология. 2005. Вып.6. C. $155-158$.

4. Cristofari G., Darlix J.L. The ubiquitous nature of RNA chaperone proteins // Progress in nucleic acid research and molecular biology. 2002. Vol. 72. P. 223-268.

5. Злобин Н.Е., Таранов В.В. Применение бактериальных белков холодового шока в биотехнологии // Вестник Московского государственного областного университета. Сер. Естественные науки. 2018. № 1. С. 86-94.

6. Изучение содержания нуклеиновых кислот в зародышах семян пшеницы разных сроков хранения / Т.А. Кокшарова, С.Р. Агамалова, Е.И. Никитина [и др.] // Исследование роли биологически активных фракторов в экспериментальном мутагенезе. Саранск, 1980. C. 42-48.

7. Зависимость содержания нуклеиновых кислот в зародышах семян яровых сортов пшеницы от места выращивания / Т.А. Кокшарова, Е.И. Никитина, С.Р. Агамалова [и др.] // Биохимия. 1969. Т. 34. Вып. 5. C. 915-919.

8. Генетические подходы в персонализации питания / А.К. Буторин., Е.Ю. Сорокина, А.В. Погожаева [и др.] // Вопросы питания. 2012. T. 81. № 6.

9. Пономарева Е.И., Алехина Н.Н., Бакаева И.А. Хлеб из биоактивированного зерна пшеницы повышенной пищевой ценности // Вопросы питания. Т.85. № 2. 2016. С. 116120.

10. Спирин А.С. Спектрофоотометрическое определение суммарного количества нуклеиновых кислот // Биохимия. 1958. Т. 23. Вып. 5. С. 656-661.

11. Практикум по физиологии растений / Н.Н. Третьяков, Л.А. Паничкин, М.Н. Кондратьев [и др.]. М.: КолосС, 2003. 288 с.

12. Добротвориева В.Г. Сравнительное изучение изменчивости содержания нуклеиновых кислот и белка у пшениц: автореф. дис. ... канд. биол. наук. М., 1966. 22 с.

13. Подшивалова А.К., Чуринова Д.Н. Влияние минеральных удобрений на биосинтез белка в процессах прорастания семян пшеницы сорта Бурятская остистая // Вестник ИрГСХА. 2019. Вып. 95. С. 30-37.

14. Подшивалова А.К., Чуринова Д.Н. Сравнительная характеристика процессов прорастания семян овса и ячменя в растворах углеводов // Вестник ИрГСХА. 2019. Вып. 90. С. $55-64$.

\section{Literatura}

1. Mamedova A.D., Aliev R.T. Izuchenie aktivnosti sinteza nukleinovyh kislot pri geterozise i stimuljacii rostovyh processov, vyzyvaemyh dejstviem gidrazida maleinovoj kisloty // Izvestija vuzov. Severo-Kavkazskij region. Estestvennye nauki. 2016. № 3. S. 3640.

2. Barashkova N.V., Neustroeva E.R. Vlijanie stimuljatora rosta «Krezacin» na rost i razvitie kostreca bezostogo v uslovijah doliny Srednej Leny // Nauka i obrazovanie. 2017. № 4. S. 99-103. 
3. Vlijanie tehnogennogo zasolenija na frakcionnyj sostav fosfornyh soedinenij rastenij / M.G. Kusa kina, O.Z. Eremchenko, N.V. Orlova [i dr.] /I Vestnik Permskogo universiteta. Ser. Biologija. 2005. Vyp.6. S. 155-158.

4. Cristofari G., Darlix J.L. The ubiquitous nature of RNA chaperone proteins // Progress in nucleic acid research and molecular biology. 2002. Vol. 72. P. 223-268.

5. Zlobin N.E., Taranov V.V. Primenenie bakterial'nyh belkov holodovogo shoka $\mathrm{V}$ biotehnologii // Vestnik Moskovskogo gosudarstvennogo oblastnogo universiteta. Ser. Estestvennye nauki. 2018. № 1. S. 86-94.

6. Izuchenie soderzhanija nukleinovyh kislot $v$ zarodyshah semjan pshenicy raznyh srokov hranenija / T.A. Koksharova, S.R. Agamalova, E.I. Nikitina [i dr.] // Issledovanie roli biologicheski aktivnyh faktorov $v$ jeksperimental'nom mutageneze. Saransk, 1980. S. 42-48.

7. Zavisimost' soderzhanija nukleinovyh kislot $v$ zarodyshah semjan jarovyh sortov pshenicy ot mesta vyrashhivanija / T.A. Koksharova, E.I. Nikitina, S.R. Agamalova [i dr.] // Biohimija. 1969. T. 34. Vyp. 5. S. 915-919.
8. Geneticheskie podhody v personalizacii pitanija / A.K. Butorin., E.Ju. Sorokina, A.V. Pogozhaeva [i dr.] // Voprosy pitanija. 2012. T. 81. № 6.

9. Ponomareva E.I., Alehina N.N., Bakaeva I.A. Hleb iz bioaktivirovannogo zerna pshenicy povyshennoj pishhevoj cennosti // Voprosy pitanija. T.85. № 2. 2016. S. 116-120.

10. Spirin A.S. Spektrofotometricheskoe opredelenie summarnogo kolichestva nukleinovyh kislot // Biohimija. 1958. T. 23. Vyp. 5. S. 656-661.

11. Praktikum po fiziologii rastenij / N.N. Tret'jakov, L.A. Panichkin, M.N. Kondrat'ev [i dr.]. M.: KolosS, 2003. $288 \mathrm{~s}$.

12. Dobrotvorceva V.G. Sravnitel'noe izuchenie izmenchivosti soderzhanija nukleinovyh kislot i belka u pshenic: avtoref. dis. ... kand. biol. nauk. M., 1966. $22 \mathrm{~s}$.

13. Podshivalova A.K., Churinova D.N. Vlijanie mineral'nyh udobrenij na biosintez belka $v$ processah prorastanija semjan pshenicy sorta Burjatskaja ostistaja // Vestnik IrGSHA. 2019. Vyp. 95. S. 30-37.

14. Podshivalova A.K., Churinova D.N. Sravnitel'naja harakteristika processov prorastanija semjan ovsa i jachmenja v rastvorah uglevodov II Vestnik IrGSHA. 2019. Vyp. 90. S. 55-64. 